\title{
ADYGHES PRESENCE CHRONICLE IN CRIMEA
}

\author{
Fatimet N. Khuako \\ Maykop state technological university. Maykop, Adygea Republic, Russian Federation \\ fatimah2@mail.ru
}

It is examined the chronology of events, accompanying the presence of Adyghe people on the Crimea territory. The article provides historical facts, proving and illustrating habitation and development of the Adyghes on Crimean land, formation of their state system, realization of domestic and external nation policy. Despite the confirmation of low study of the problem, the author enumerates contemporary works of foreign (in particular, I. Klingen "Basis of economy in the Sochi district (1897)) and national scientists, and basing on this point begins to present old events of XVII - XIX c. exposing not only trade and political, but also friendly relations. The biography of Russian tsar Ivan the Terrible connected his life with Circassians by marriage on their representative in the days of Kemirgoko Idarov rule appears the apotheosis of this relation. Considering the military operations, captures and attacks, produced by rulers on the described territories in the examined period, it is illustrated the required coil of state contacts and a thesis about the Adygeis presence in Crimea. Underlining mention of Inal in folklore Adygei texts and establishing an appeal to this image in works of S.Khan-Girey and Sh.Nogmov, it is traced the fate and asserts the influence on the ethnos. Analysing the study of Inalids imperious period by the modern historians - A.Ostashko "Circassians and Crimea", A.Maksidov "Historical and genealogical connections of the Adygeis with the people of Black sea Region" and F.Ozova "Cherkes-Italian historical crossing and parallels", the author of the article mainly accepts their arguments and explains the position that allows to line up a personal reasonable construction.

Key words: Crimea, Circassian, Adyghe, connection, history.

\section{[Хуако Ф.М. Хроника присутствия Адыгов в Крыму]}

Рассматривается хронология событий, сопровождавших присутствие адыгского народа на территории Крыма. Приводятся исторические фракты, доказывающие и иллюстрирующие обитание и развитие адыгов на крымских землях, становление их государственности, реализацию внутренней и внешней политики нации. Отталкиваясь от утверждения малой изученности, автор перечисляет имеющиеся труды зарубежных (в частности, И.Клинген «Основы хозяйства в Сочинском округе (1897 г)) и отечественных ученых (и прежнего, и нового времени), автор освещает давно-вековые события XVII - XIX вв. Выявляя не только торгово-политические, но и родственные связи между Крымом и Черкесией, описываются разнообразные детали данных взаимоотношений, выводятся на первый план неизвестные ранее подробности правления (в частности, Инала) и разносторонне тем самым доказывает интенсивное наличие искомых крымско-черкесских связей. Апофеозом таковых оказывается биография русского царя Ивана Грозного, связавшего свою судьбу с черкесами женитьбой на их представительнице во времена правления Кемиргоко Идарова. Рассказывая об имевших место военных операциях, захватах и нападениях, производившихся правителями на описываемых территориях в рассматриваемый период, Ф.Н.Хуако иллюстрирует требуемый виток государственных контактов и выдвинутый им изначально тезис о присутствии адыгов в Крыму выглядит несомненным и бесспорным. Подчеркивая упоминание Инала в фольклорных текстах адыгов и констатируя обращение к этому образу в работах С.Хан-Гирея и Ш.Ногмова, автор прослеживает его судьбу и утверждает влияние на этнос. Анализируя изучение властного периода Иналидов современными историками А.Осташко «Черкесы и Крым», А.Максидовым «Исторические и генеалогические связи адыгов с народами Причерноморья» и Ф.Озовой «Черкесо-итальянские исторические пересечения и параллели», автор преимущественно принимает их аргументы и объясняет свою позицию, что позволяет ему выстроить собственную обоснованную конструкцию.

Ключевые слова: Крым, черкес, адыг, связь, история.

Fatimet N. Khuako - Ph.D. of philosophy, professor. Maykop state technological university. Maykop, Adygea Republic, Russian Federation. 
Хуако Фатимет Нальбиевна - доктор филологических наук, профессор. Майкопский государственный технологический университет. г. Майкоп, Республика Адыгея, Россия.

It seems that today in newly acquired territory for Russia (Crimea), induced a lot of discussions (more often, - agreements), disputable and unlighted layers are absolutely absent. The ethnos of Adyghes (the Circassians) straightly acts as a similar concealed layer, predominantly treated and continues to be concealed by the domestic researchers in their writings. Here, for instance, one opens the today's issues of the Literary Newspaper (2017. 24-30 of May). The volume article of Marina Matveeva "For those, who is constantly searching for fight", enthusiastically devoted to one of Crimean curative health resorts Saki. Beautifully describing Crimean territories, merely acknowledging their attendance not for the first century, especially, - distinguished with ranks (M.P. Lazarev and others.), she enumerates Russian generals conquered these lands, as "honorary guests" and she is proud of such visits on behalf of inhabitants. However, she does not say a word about native persons, who inhabited this land and then lost it.

In contrast to this obvious default we will further see the available versions of events happened there in science and history, overboard of which people, inhabited this land could not stay. Moreover, the presence of the Adyghes in the Crimea nevertheless turned out to be an object of detailed study for some authors (more often, foreign or national). In particular, the German traveler Ivan Klingen, whose work "Economy principle in the Sochi district (1897)" was published in our days by Samir Khotko, who quite in detail and rather considerably pays scientific attention to the Circassian patrimonial lands. He figuratively and expressively manages to elucidate history, without impinging interests of native persons: "Roman patricians came here in painted ships to rest in their neat and cozy villas. India and Central Asia sent caravans with rare commodities through the riverside cities, and the country itself exported its rare agricultural pieces of work" [2]. Besides, prerevolutionary traveler I. Klingen defines Adyghe horsemen as "warriors-eagles, so gifted from nature" [2]. But our contemporary A. Ostashko, says that "In the Caucasus the Circassians represented those, whom French were in Europe: trendsetters - in costume, with weapon, in saddle, in riding manner, with laws, customs and mountain etiquette. They also became the same in the Crimea" [5].

The authors of the following centuries also referred to this problematic. Thus, in particular, A.A. Maksidov (Nalchik, 2001), emphasizes already in modern candidate thesis on the historical topic, describing the work of the historian, soviet time publicist Kh. A. Porksheyan, who "marks the most archaic layers of Adyghe presence on the half-island, toponyms with the "Circassian" basis [3, p.195]. The Genoese presence in Circassia has also been examined in detail in the work of the last century historians of the 1930s., E.S. Zevakin and N.A. Pencko. They mark the high ethno social status of Circassians in the Genoese cities in Crimea, and also in Venetian Tana. "Trade with Cirkassia was so profitable, - as marked the other domestic historians of an early soviet period (30-s) E.S. Zevakin and N.A.Penchko, - that despite various obstacles, Italian merchants strove to tie firm relations" [3, p. 379-380]. Besides, according to A.A.Maksidov, "In the end of XVIII beginning of XIX $\mathrm{c}$. hardly all the authors shared the corresponding opinion. Argumentation of Circassian presence in Ukraine in the unfolded view given in the labors of Al. Rigelman, Af. Shafonskii, M.I. Antonovskii. They attracted a significant ethnographical material on the regions of Poltava, Chernigov, Kanev, Chigirin, Cherkassy" [3, p. 7]. We agree with the authors of the past centuries, continuing further, we will develop an analytical thread of the 2000s thesis defender Anatoly Maksidov, which is a very thorough and consistent work that has focused a lot on the Crimean-Adygea problems. 
Adyghes, in the role of North-Caucasian ethos representatives, appeared to be stable inhabitants of Crimea during four centuries (XII - XV c.) Under this they rather intensively influenced on its development chronology, however, more often appeared to be only dissoluted in the quantitatively predominant people, who were Crimea Tatars, Byzantines, Genoeses. Nevertheless, this did not disturb the Adyghe coast of the Black Sea to stay really active, significant center of global trade business during two centuries. The trade turnover of high-quality goods (grain, textiles, leathers and fur, steel and alloys) produced here was an obvious financial source for the Adyghes. In a similar way, the country of Circassians took part in the world trade reforms of the XIII century (1160s - 1330s), from which archives in Italy have been preserved.

The mention that in the initial phase of the stated period (XII c.) a certain part of Adyghes already inhabited Crimea spaces, from the number of whom, as is known, Mamelukes were composed in the army ranks of the Egyptian rulers, considered to be the acknowledged fact among the scientists. As it stated in the modern site of "Komsomolskaya pravda" (https://www.kuban.kp.ru/daily/26686.4/3709261) by V. Lagovskoi, on the basis of German scientists conclusions of acknowledged scientific organizations (Max Planck Institute for the Science of Human History and University of Tuebingen), partly reproduced by the geno of ninety Egypt mummies (age - from 3500 to 1500 years), the ancient Egyptians were colorful in their multinational, and far from Africans. The part of them was from Turkey, the other part genetically appears to be the south Europeans, and also newcomers from Lebanon, Israel, Jordan, Syria, Georgia and Abkhazia. Here one emphasizes that representatives of the last mentioned territories belong with Adyghes to the united adyghe-abkhazian language group and appeared to be the ethnos related to the Circassians, and that is why immediately enter into investigated preimage.

But return to the Crimean lands. The rulers of the eastern Crimea territories (in particular, at that time - Vosporo, today - Kerch) were Adyghe princely persons. According to the convincing opinion of the modern historian F.A.Ozova, they were a number of Adyghe princes: in1320-s. - Verzakht, in 1330-s. - Millen, in 1370 - 1380-s. - Zhankasius-Zikh (Circass-bek) [4, p. 147]. Trade exchanges of the planetary level thereat contributed to the emergence of thirty-nine settlements from Genoa in Circassia XIII - XV centuries. The coIonies were located both in the Black Sea and Azov seaside areas, occupying the space between the main trade points, at that time - Sebastopolis and Tana, now - Sukhumi (Abkhazia) and Azov (Crimea). As chronologist F.A. Ozova quoted there considers that resettlement of Genoeses to Adyghe lands of XIII c. directly occurred at that time confirms rather significant degree of socioeconomic level, existing among the Adyghes, proves the presence of "conditions for commodity-money relations and constant trade" in the society. This thesis is confirmed by the written sources and archaeological material of $X$-beginning of XIII c." [4, p. 148]. Further, a certain leveled position in society for the Circassian princes and Genoese continued, which the quoted historian calls clearly marked on the "Catalan map of 1375" and expressively describes historical metaphors: "Genoese flag flutters over Kafa, the flag with Genghisides coat-of-arms and Islamic half moon - over Tana, and there is a fortress with a minaret, but without identification marks on the right bank of the Kuban in the area of modern Krasnodar". "Archaeologist N.G. Lovpache defines it as the northern stronghold of independent Circassia" [4, p. 147]. The Crimean Khanate, dating from around 1430, formed in the next century, is considered to be founded by Khadzhi Giteey, descendant of Tug-Timur.

At the same time, in addition to trade and political relations, modern scientists have convincingly recognized certain genealogical relationships, a link through which interaction between Crimea and Circassia also often took place. Numerous facts of the Tartar Gireys families creation with Circassian women from different (Khatukaevskaya, Kabardian, Besleneevskaya, Temirgoyevskaya, Janeievskaya, Bzhedugskaya) princely families tangibly 
rallied the nobility of the two spaces. This conditioned the appearance of separate social group in Circassian world, basing on the affinity with khan - khanuko. The ancestry relations and family bounds accompanying them were rather mighty that in its turn induced formation on the differences absence of some "adyghe-italian community, representatives of which spoke in English language and were Catholic", whom A.A. Maksidov calles ferendge-circassian [3, p. 15].

It is obvious here that Adyghes strove to build sound ties with khans by means of diplomatic marriages of the second one on Adyghe heiresses and with acquisition of following respectful status by khan elite. The presence of Circassian country on the "Political map of the Black Sea region", composed after Crimea khanate deprivation and mentioned in the today's Wikipedia is largely induced by the corresponding family contacts (https://ru.wikipedia.org/wiki/). The following acquisition of the authority by khans formed the favorable environment for the Adyghe government on the international level. Direct activity of unequally social, so mentally connected Adyghes and Crimea Tatars were in danger at the stage of Crimea khanate functioning. At first a certain north threat was involved. Secondly, italo-circassian trade bounds were forgotten, as were removed from the moment of Constantinople conquest by the Turks (1453) and, moreover, after Kafa conquest later (Feodosiya), in two decades (1475).

However, there was a Circassian ruler of princely descent, whose aspirations (sometimes productive) to a coalition of available tribal differences simplified the depreciation of local authorities that enabled the Kabardians to divide the modern state formation into the colonies. Knyazh Inal acted as such, the grandfather of whom (named Akabu) according to the legends was originated from Crimea, and he himself was a great-great-grandfather of Ivan the Terrible (Kemirkogo) father-in-law (20). There one should prescind a little bit to chronology of King Ivan the Terrible private life, as he plays a major role in Crimea existence. According to the modern historian Zaurbek Kozhev, the events chronicle accompanied the marriage obviously demonstrates the political disagreements, peculiar as for the Kabardians Idarovs originated from Inal, so for Zhaneievts Kansaukovs. During the occurring hazards the first of them decided to obtain rather strong and stable partner at the global arena. They did it, had agreed on the marriage of Idarovs the youngest daughter with Ivan the Terrible. The second one wanted to escape the genealogical alliance forming with the neighboring ruler of Russia, losing possibilities for patronage. At this moment knyazhs found the Adyghe countries. Inal began to insistently transform the empire weakened by delimitation into some feudal principalities, embodying the project of united Circassian territories reconstruction. However, at the same time he tried to attach Abkhazian lands to its borders, which also affected Georgian interests (who had military experience back in the $30 \mathrm{~s}$ of the XV century). At that time he managed to prevent Italian invasion to the domestic political arena, sometimes relying on the authority of his royal relative.

The princely patrimonial title delivered for term of life to the heirs had a place in history of Adyghe aristocracy. Accordingly, the idea of Kemirgoko Idarov, which shocked the countrymen in 60-s of XVI c. appears to be in some degree explicable. He went to the Russian tsar with the initiative to form a fortress with continuous protection in the princely space (near the river Terke). This idea was interpreted by fellow countrymen and the following generations as Idarov's reaction to the danger from the East-Caucasian Dagestani state. Consequently, in 1567 Ivan the Terrible ordered and equipped two or three thousandth garrison, accompanied by an instrumentally equipped brigade for the construction of fortress walls. The required initiative of the prince was thereby successfully implemented.

The military-political and managerial successes achieved by representatives of the Inalid family proved to be impressive. Therefore, both the Adyghes, and the neighboring people contacting with them, respectfully and with reverence mention Knyazh Inal in their 
folklore texts. For example, his image is present in the Kabardian version of the epic - "Inal Nef" (Adyghe Inal the Light). The Adyghe writers-enlighteners S.Khan-Girey and Sh.Nogmov, and the others continued to develop the epic legend in XIX c. The origin of the dominant family branch of Inalid is represented as a legend in the epic source, the plot of which is based on the arrival of two rulers (Circassians, Bekes) from Iraqi lands to Egypt, who confronted the Turkish kingdom, fought, but died in battles. The continuers of their policies, their related rulers fought on the Syrian lands, but also unsuccessfully. One of them (Arab Khan), hiding in Roman squares, was sent by the ruler to the river Kabarta, as the northern boundary of the state. A.Ostashko browses the distinct Circassian prints at the given territory. Reasonably speaking, the Kabardians placed their settlements that belonged to the principality of Feodoro along it, he stops to explain the details attributed to the village of Foti-Sala (present-day v.Golubinka) (Adyghe "a village giving honey"), considered to be the northern border of the named principality. Stating numerous civilization facts of these territories existence, A. Ostashko gives vivid and diverse examples of archaeological and chronicle evidences. In the process of internal political turmoil, the heir of the Arab-khan (Abdan-) was compelled to settle with his family in the West Caucasian Circassian lands, where by that time his son Kes was already a ruler. As a result, the grandsons of Dalia (Ado and Khurofatlai) were in power, then Inal came (whom the Georgian chronicles called "Inal the Great"). Following the death of Inal on the river Bzib' in 1453, his heirs failed to preserve his father's inheritance. Here the dispute for the supremacy was activated, in which other Adygean aristocrats joined in. As a consequence, the state was again divided into independent territories under the control of the princes.

The specificity of Genoa settlements management tool on the Circassian coasts was as follows: the Genoese were located under some kind of "supervision" of the regional authorities, as the Russian travelers E.D. Felitsyn and L.I. Lavrov, drew conclusion, tracing the clear dependence on the tribute of the first, collected by the second. Turkish invasions put a period of Genoa at Circassian lands to the end in 1475. Turkish ships which occupied Kafa in Crimea ports, gradually conquered Anapa, Kopa, Bata, in the Circassian Black Sea region. In the course of numerous Turkish campaigns a lot of Circassian rows were diminished, keeping the defence of bond buildings. However, thank to their desperate defence Taman appeared then unconquerable. And only under the command of sultan Bayazet II the Crimea was conquered by Turkish people. After the given deforcement commitment in1484, they tried to build real influence on the Circassians through the Crimea khans, who were under vassal subordination of Turkish authorities.

Some part of Circassian warriors who could preserve their lives hid in the Caucasus. The other part stayed to adapt to that social environment, where their countrymen with whole families became coming from Caucasian mountains to get employed to this or that khan laborer. Thus, for instance, according to the modern researcher A. Ostashko, with whom many national scientists unanimously agree, "Auls were one of the Circassian settlements of that time in the Crimea - Tiberti (modern Turgenevka) and Syuryu-Tash (modern v. Belokamenka) near Bakhchisarai". The "Circassian quarter" was located in the Genoese Kaffe, whose mayor's office periodically cooperated with the Adygean soldiers and formed a security service, and in the mountains near Karasubazar there was aul Baksan (modern Mezhgorye village), which was part of the Genoese consulate Soldai" [5].

However, this career focus did not prevent the khans from continuing to disturb the country of the Circassians, and this, in its turn, forced the Adyghes to go to the ruler of Porta. If take into consideration of military technologies acknowledged for centuries then one can confirm that the Circassians were willingly and greedily accepted to militaristically expected work. After the time required for professional training, the Circassian families offered their own candidate to power in the face of a military man who had some authority in the region. Consequently, the Kuban and Taman territories populated by the Adyghes 
were considered to be federal, but were not subjected to the Crimean hierarchy. Within these limits, geographically conditioned military clashes periodically broke out, which lasted until the 1950s. of XVII century. As I.N. Klingen says about the finale of Kabarda in Crimea, the Circassians "did not want to get into a quarrel with the Orthodox people, and state necessity wiped them off with one mighty impulse". And about the consequences of such historical turns for the Circassians, he emphasizes: "The mountaineers disappeared, but with them the knowledge of local conditions, their experience, the wisdom of the people that makes the best treasures among the poorest people and which should not be disdained even by the most cultured European" [2].

\section{Лumepamypa}

1. Зевакин E.C., Пенчко Н.А. Очерки по истории генуэзских колоний на Западном Кавказе в XIII и XV веках: Исторические записки. Т. 3. М, 1938.

2. Клинген И.Н. Старые черкесские сады: Ландшафт и Агрокультура Северозападного Кавказа в освещении русских источников. 1864-1914. Т.2. / Составитель С.Х.Хотко. aheku.net

3. Максидов А.А. Исторические и генеалогические связи адыгов с народами Причерноморья: Автореферат. Диссертация на соискание ученой степени кандидата исторических наук. Нальчик, 2001.

4. Озова Ф.А. Черкесо-итальянские исторические пересечения и параллели // Археология и этнология Северного Кавказа. Сборник научных трудов к 75летию Исмаила Магомедовича Чеченова. Нальчик, 2013. Вып. 2.

5. Осташко A. Черкесы и Крым [Электронный ресурс] // https://www.facebook.com/permalink.php?id=248633771877008\&story_fbid=57242 $1926164856(12.08 .17)$

6. Поркшеян Х.А. Переселенные из Крыма армяне и черкесы на Дону: Ученые записки. Кабардино-Балкарский НИИ. 1959. Т. 15.

\section{References}

1. Zevakin E.S., Penchko N.A. Essays on the history of the Genoese colonies in the Western Caucasus in the XIII and XV centuries: Historical Notes. Vol. 3. M, 1938.

2. Klingen I.N. The old Circassian gardens: Landscape and agriculture of the northwest Caucasus in the presentation of Russian sources. 1864-1914. Vol. 2 / Composed S.Kh.Khotko. aheku.net

3. Maksidov A.A. Historical and genealogical bonds of Adyghes with the Black sea region people. Thesis for the candidate of historical sciences. Nalchik, 2001.

4. Ozova F.A. Circasso-Italian historical crossings and parallels // Archeology and ethnology of the North Caucasus. Collection of scientific papers to 75-th of Ismail Magomedovich Chechenov. Nalchik, 2013. No. 2.

5. Ostashko $A$. the Circassians and Crimea [Electronic resource] // https://www.facebook.com/permalink.php?id=248633771877008\&story_fbid=57242 1926164856

6. Porksheyan Kh.A. The Armenians and Circassians on the Don emigrated from Crimea: Scholarly notes. Kabardino-Balkarian SRI. 1959. Vol. 15. 